\title{
'Supernatural, or at Least Romantic': the Ancient Mariner and Parody
}

Steven Jones

Sjones1@luc.edu

Follow this and additional works at: https://ecommons.luc.edu/english_facpubs

Part of the English Language and Literature Commons

\section{Recommended Citation}

Steven E. Jones, "'Supernatural, or at Least Romantic': the Ancient Mariner and Parody," Romanticism on the Net, 15 (August 1999).

This Article is brought to you for free and open access by the Faculty Publications and Other Works by Department at Loyola eCommons. It has been accepted for inclusion in English: Faculty Publications and Other Works by an authorized administrator of Loyola eCommons. For more information, please contact ecommons@luc.edu. c) (i) $\Theta \Theta$

This work is licensed under a Creative Commons Attribution-Noncommercial-No Derivative Works 3.0 License. (c) Michael Eberle-Sinatra 1996-2006. 


\section{'Supernatural, or at Least Romantic': the Ancient Mariner and Parody [*]}

Steven E. Jones

Loyola University Chicago

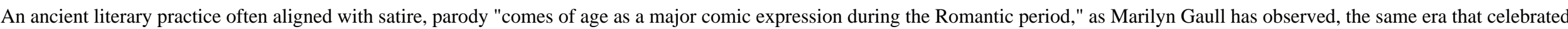

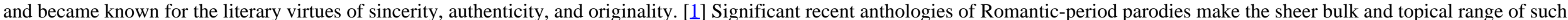

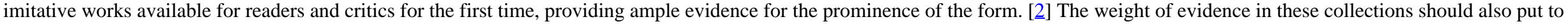

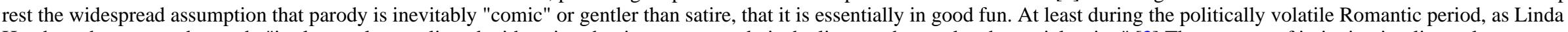

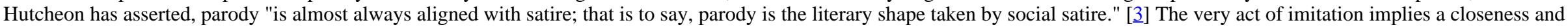

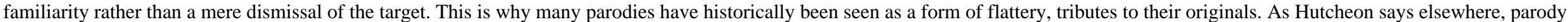

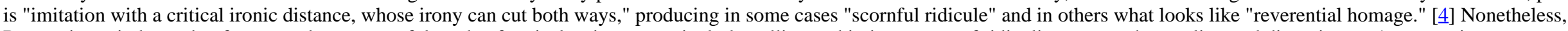
Romantic-period parody often served as a powerful mode of topical satire-a particularly galling and intimate way of ridiculing a target by stealing and distorting one's very voice.

2

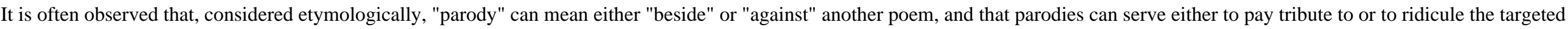
work. Samuel Taylor Coleridge approached the same matter from a slightly different direction in the following epigram for anonymous inclusion in Robert Southey's Omniana:

Parodies on new poems are read as satires; on old ones, (the soliloquy of Hamlet for instance) as compliments. A man of genius may securely laugh at a mode of attack, by which his reviler in half a century or less, becomes his encomiast. [ㅁ]

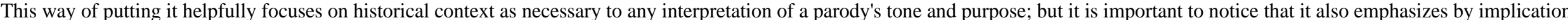

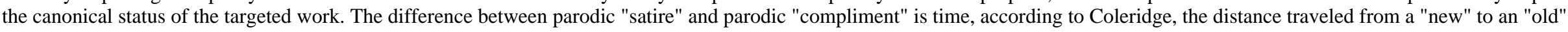

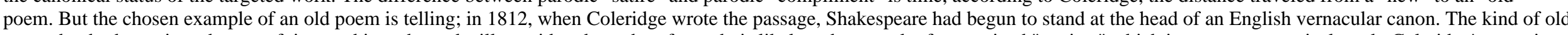

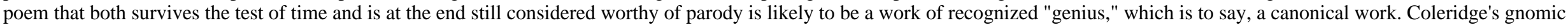

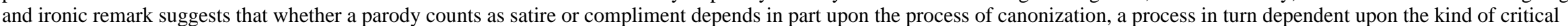

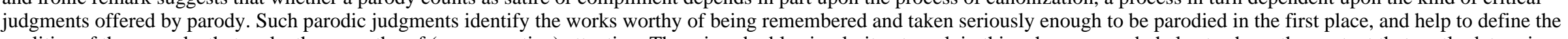

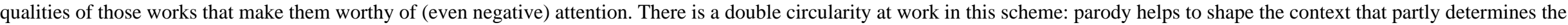

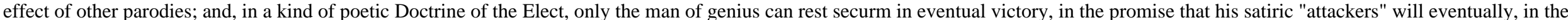

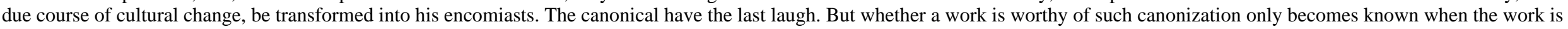

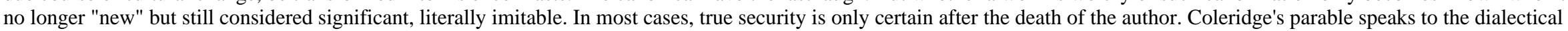

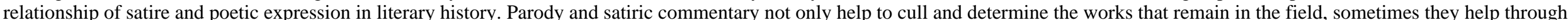

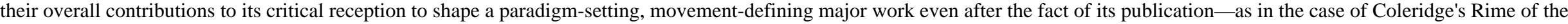
Ancient Mariner.

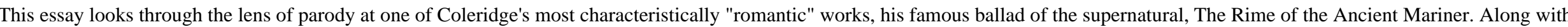

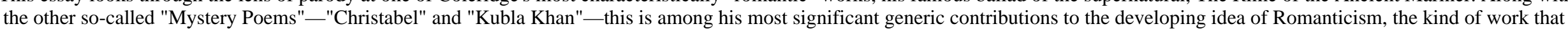

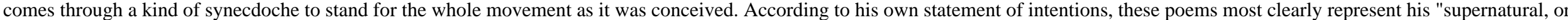

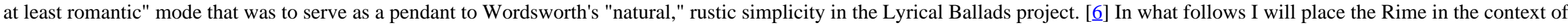

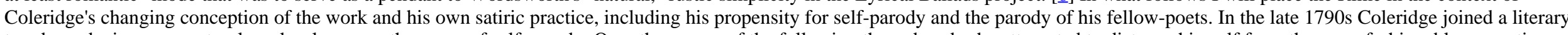

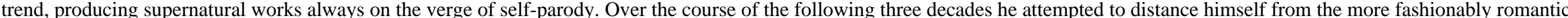

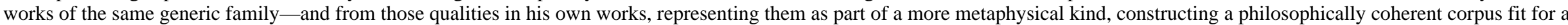
place in the canon. Parody, broadly conceived, plays a role at every stage of this process.

\section{The Ancient Mariner and the Romantic Canon}




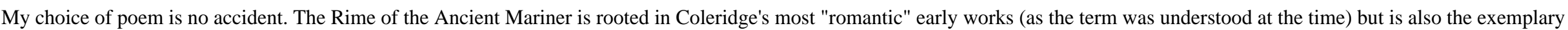

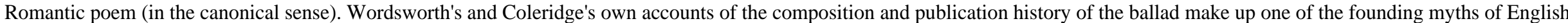

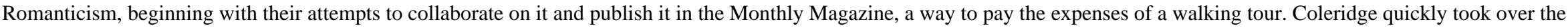

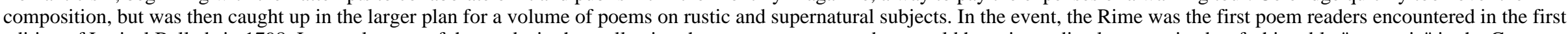

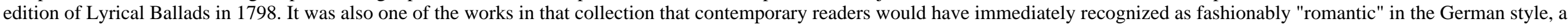
kind of gothic horror ballad then popular in the magazines. As an anonymous reviewer looking back from twenty years later noted, The Rime of the Ancient Mariner

appeared at a time when, to use a bold but just expression, with reference to our literary taste, 'Hell made holiday,' and 'Raw heads and bloody-bones' were the only fashionable entertainment for man or woman. Then Germany was poured forth into England, in all her flood of sculls and numsculls: then the romancing novelist ran raving about with midnight torches, to shew death's heads on horseback, and to frighten full-grown children with mysteries and band-boxes, hidden behind curtains in bedrooms . . . [7]

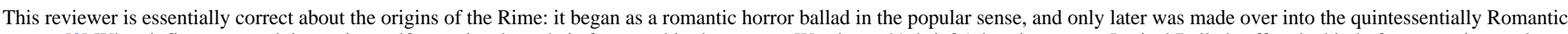

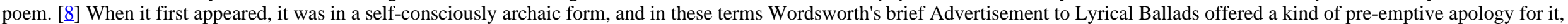

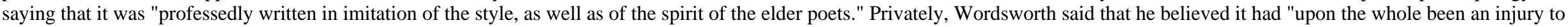

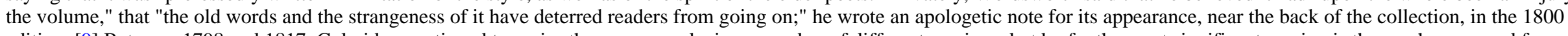

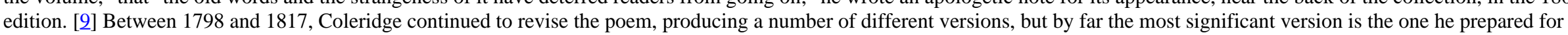
publication in his own Sibylline Leaves of 1817.

5

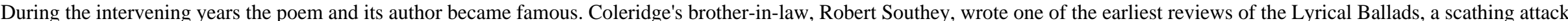

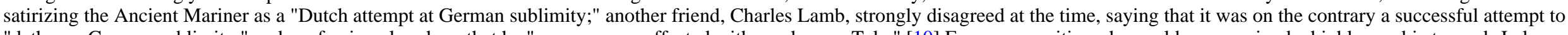

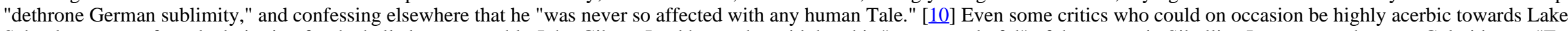

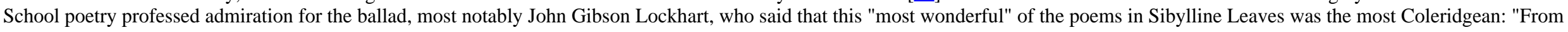

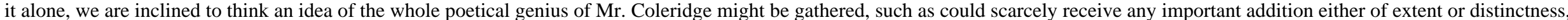

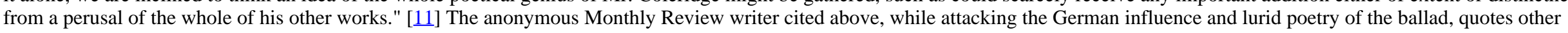

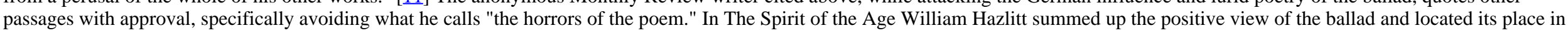
Coleridge's oeuvre:

Of all Mr. Coleridge's productions, the Ancient Mariner is the only one that we could with confidence put into any person's hands, on whom we wished to impress a favourable idea of his extraordinary powers. Let whatever other objections be made to it, it is unquestionably a work of genius-of wild, irregular, overwhelming imagination, and has that rich,

varied movement in the verse, which gives a distant idea of the lofty of changeful tones of Mr. Coleridge's voice. [12]

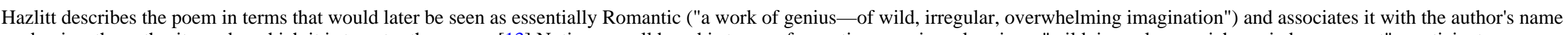

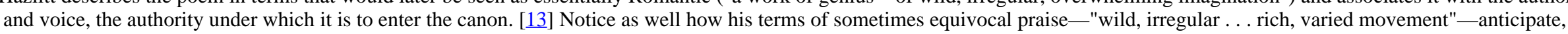

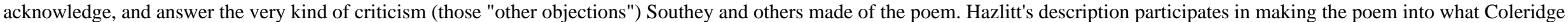

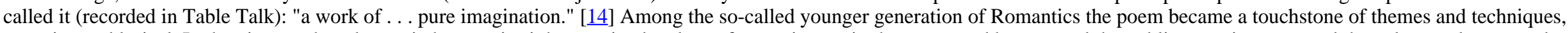

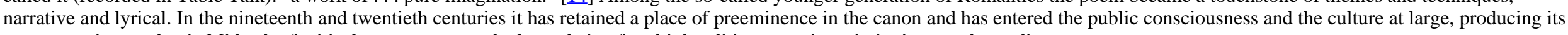
own extensive academic Midrash of critical commentary and a long chain of multiple editions, versions, imitations, and parodies. 6

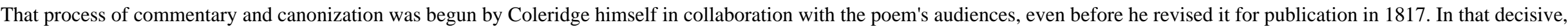

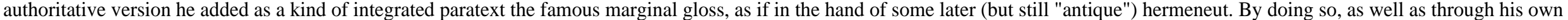

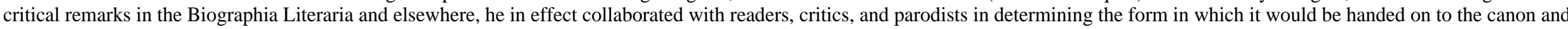

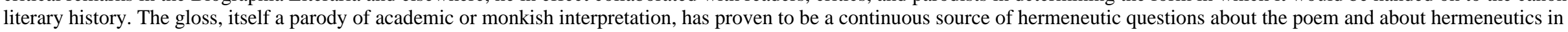

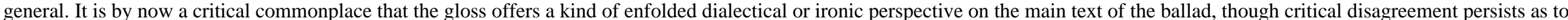

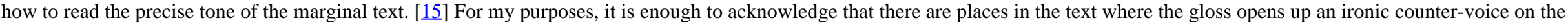

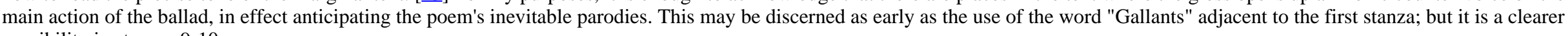
possibility in stanzas 9-10:

The bride hath paced into the hall,

Red as a rose is she;

Nodding their heads before her goes 
The merry minstrelsy.

The Wedding-Guest he beat his breast,

Yet he can not chuse but hear;

And thus spake on that ancient man,

The bright-eyed Mariner. [16]

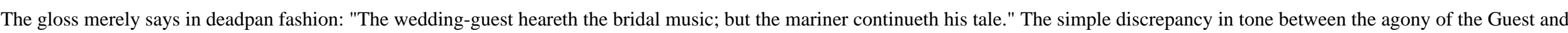

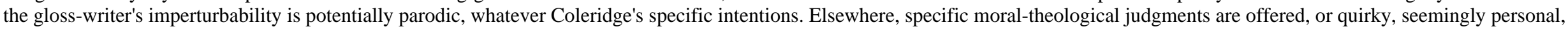

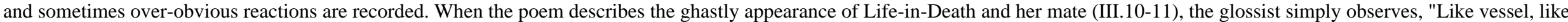

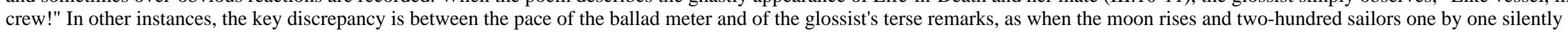

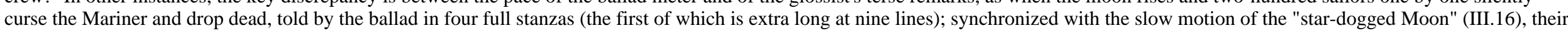

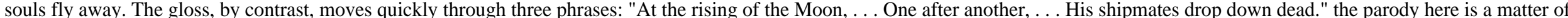

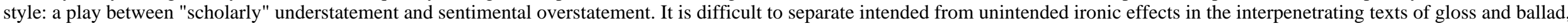

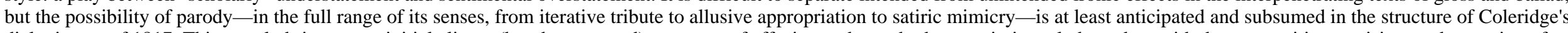

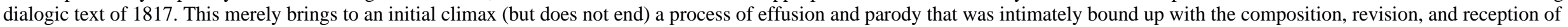
this most "romantic" of Romantic works.

\section{Two parodies: 1819, 1989}

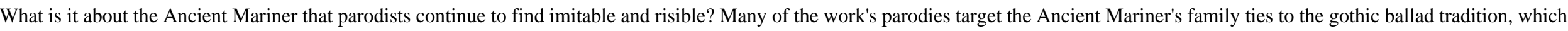

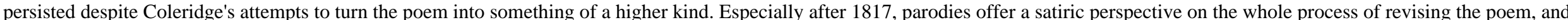

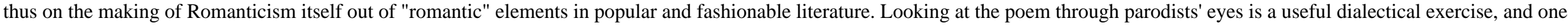
that provides a counterweight to the institutionalized academic readings of the poem as a central text in the High Romantic canon.

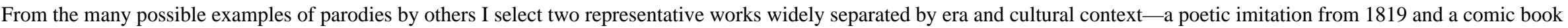

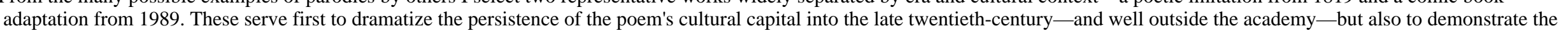

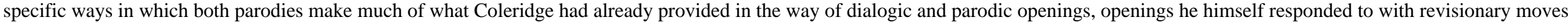

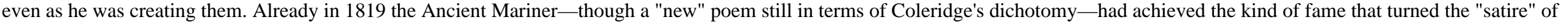
any parody into something of a "compliment." The work's reception and legacy was shaped by the interaction of such canonizing compliment and satiric commentary.

\section{1819}

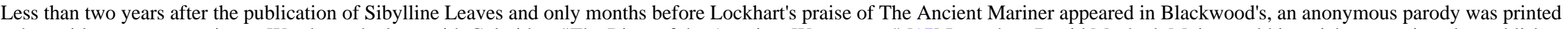

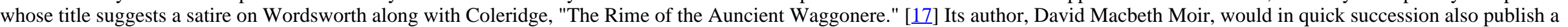

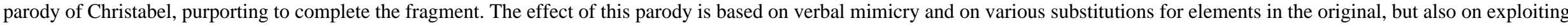
the discrepancies between gloss and main text.

IT is an auncient Waggonere,

And he stoppeth one of nine:-

"Now wherefore dost thou grip me soe

With that horny fist of thine? 
"The bridegroom's doors are opened wide,

And thither I must walke;

Soe, by your leave, I muste be gone,

I have noe time for talke!"

Hee holds him with his horny fist-

"There was a wain," quothe hee,

"Hold offe, thou raggamouffine tykke,"

Eftsoones his fist dropped hee.

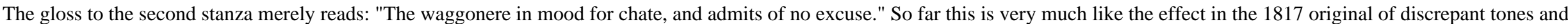

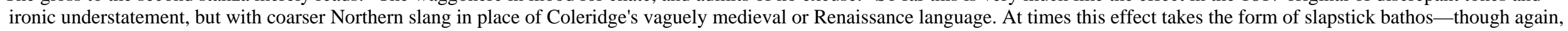
the original had provided the example and pointed the way:

"The wain is fulle, the horses pulle,

\section{Merrilye did we trotte}

Alonge the bridge, alonge the road,

A jolly crewe, I wotte:"-

And here the tailore smotte his breaste,

He smelte the cabbage potte!

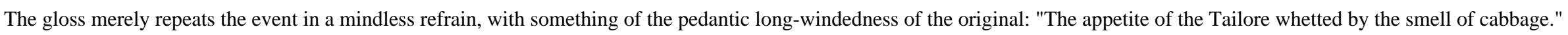

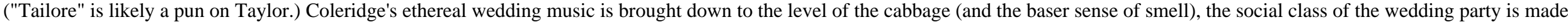
clear, and the parody mocks the intrusion of quotidian details — and the body —into the melodramatic action and supernatural or psychological effects of the original ballad.

10

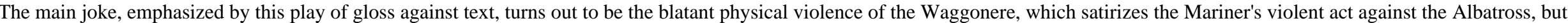

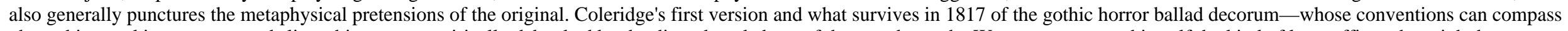

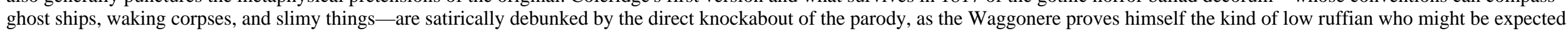
by Blackwood's readers to appear in a ballad.

"At lengthe we spied a goode grey goose,

Thorough the snow it came;

And with the butte ende of my whippe,

I hailed it in Goddhis name.

"It staggered as it had been drunke,

So dexterous was it hitte;

Of broken boughs we made a fire,

Thomme Loncheone roasted itte."- 


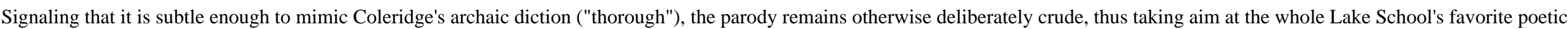
virtue of "simplicity." The power of the Waggonere to hold the Tailore as an audience begins to look increasingly like thuggish intimidation.

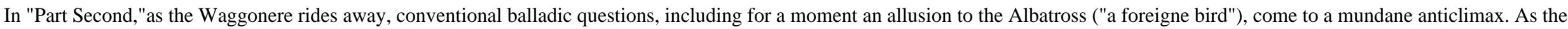
gloss says: "Various hypotheses on the subject, frome which the passengers draw wronge conclusions."

"Some saide itte was ane apple tree,

Laden with goodlye fruite,

Some swore itte was ane foreigne birde,

Some said it was ane brute;

Alas! It was ane bumbailiffe,

Riding in pursuite!

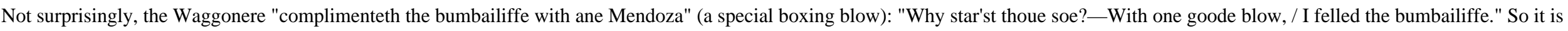
with less metaphysical than physical dread (what the gloss names "Corporal Feare") that this interlocutor says,

"I feare thee, auncient waggonere,

I fear thy hornye fist,

For itte is stained with gooses gore,

And bailiffe's blood, I wist.

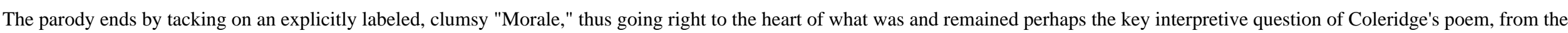

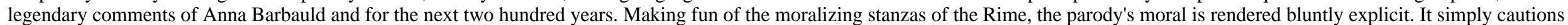

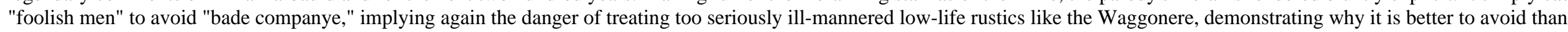

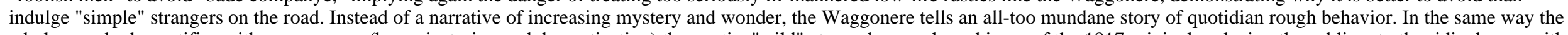

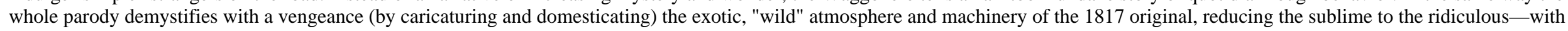
a brickbat.

12

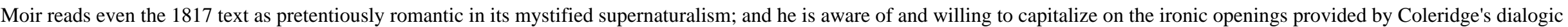

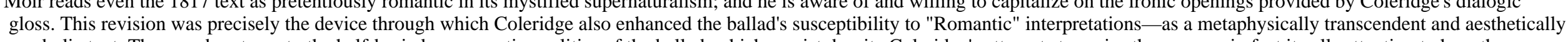

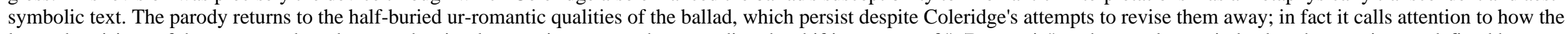

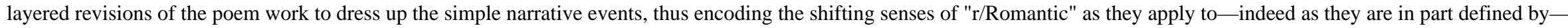
Coleridge's poetry.

\section{1989}

13

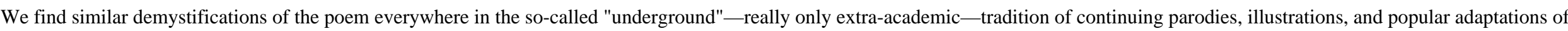

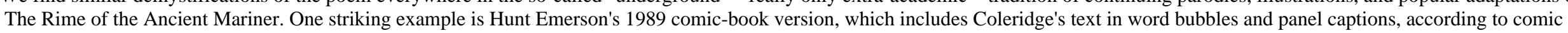

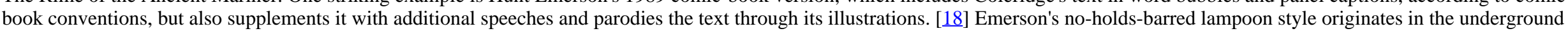

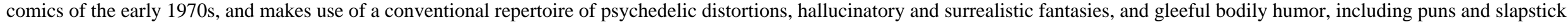

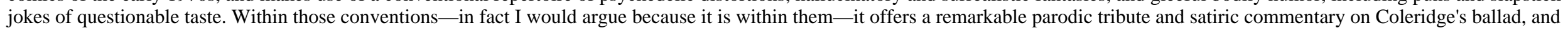


on its long reputation and vast store of accumulated cultural capital.

14

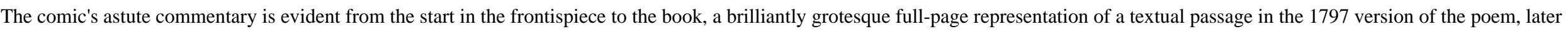
deleted by Coleridge as too luridly "German," in which the living-dead sailors raise their arms to burn as lurid torches:

A little distance from the prow

Those dark-red shadows were;

But soon I saw that my own flesh

Was red as in a glare.

I turn'd my head in fear and dread,

And by the holy rood,

The bodies had advanc'd, and now

Before the mast they stood.

They lifted up their stiff right arms,

They held them strait and tight;

And each right-arm burnt like a torch,

A torch that's borne upright.

Their stony eye-balls glitter'd on

In the red and smoky light.

1798; VI.485-98

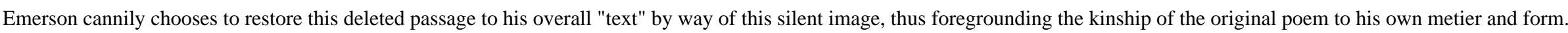

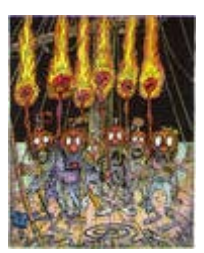

Image pleine grandeur

15

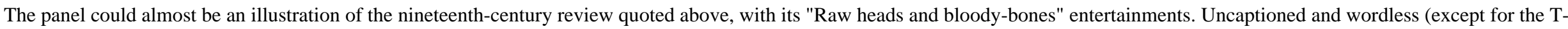

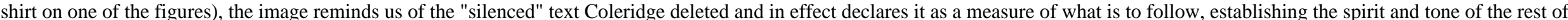

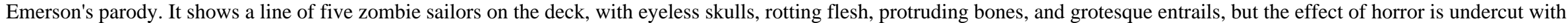




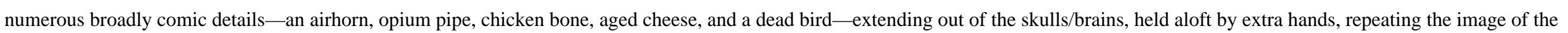

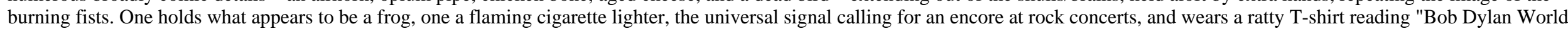

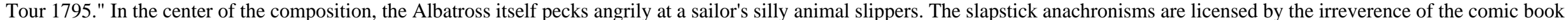

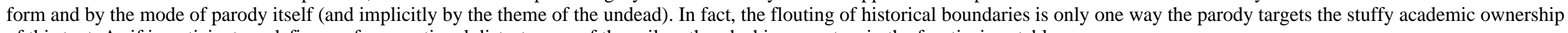
of this text. As if in anticipatory defiance of conventional distaste, one of the sailors thumbs his nose at us in the frontispiece tableau.

16

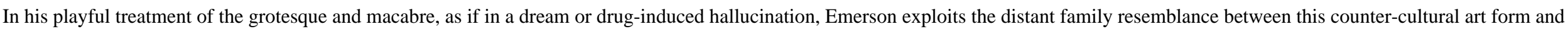

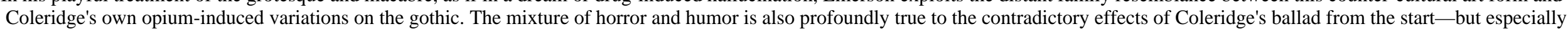

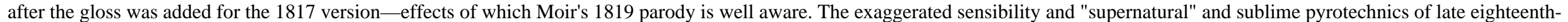

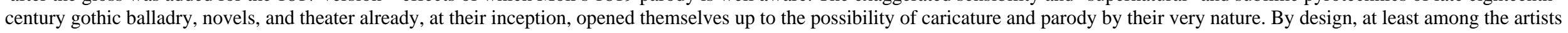

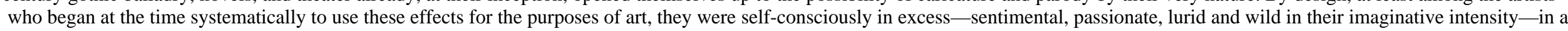

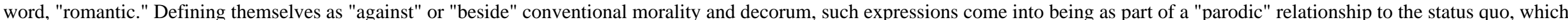

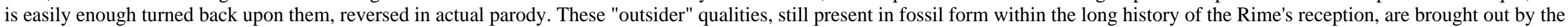
historically distant and yet generically consonant, exaggerated and distorted psychedelic exuberance, of Emerson's comic-book style.

17

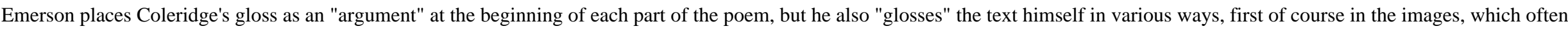

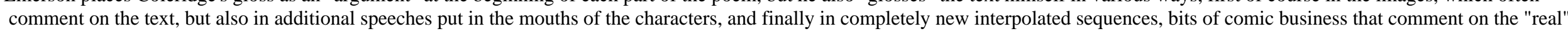

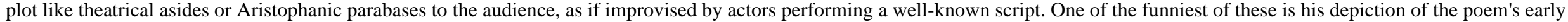

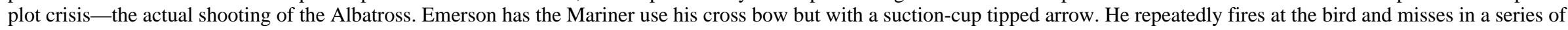

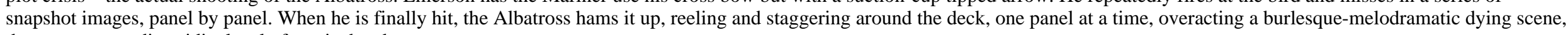
the arrow protruding ridiculously from its head.

Figure

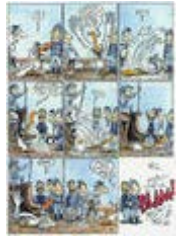

Image pleine grandeur

18

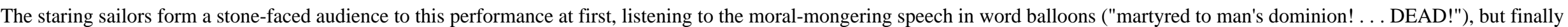

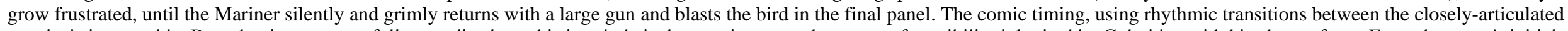

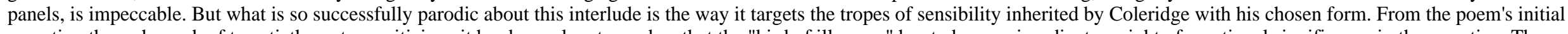

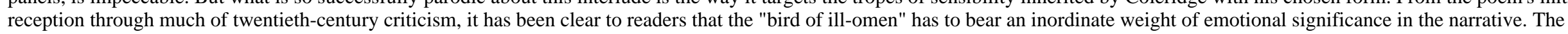

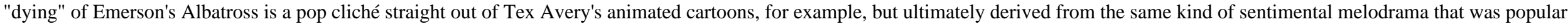

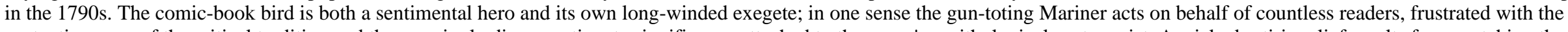

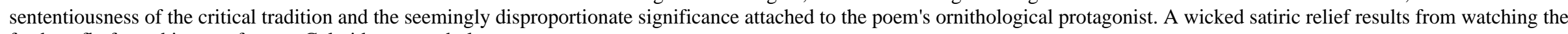
feathers fly from this most famous Coleridgean symbol.

19

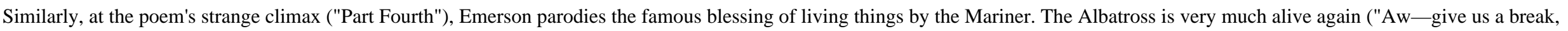

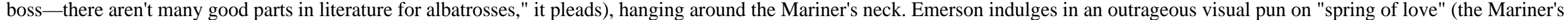

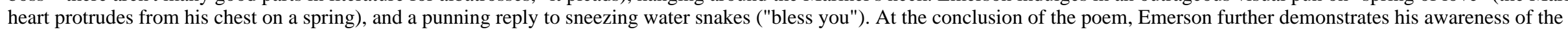




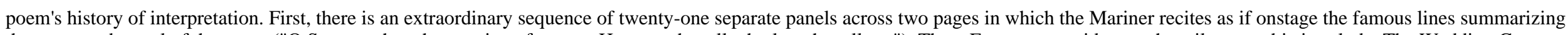

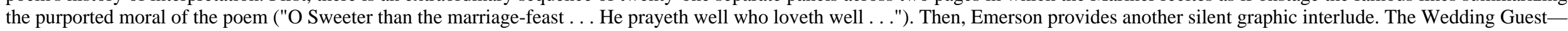

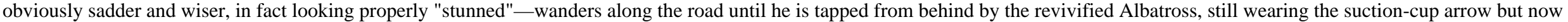

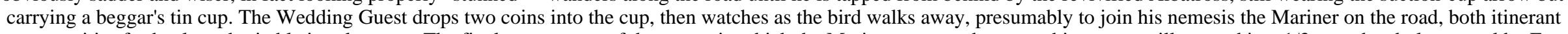

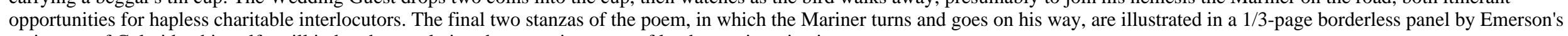
caricature of Coleridge himself, quill in hand, completing the poem in a state of laudanum-intoxication.

Figure

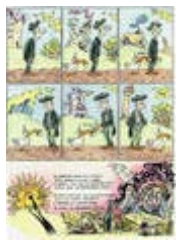

Image pleine grandeur

20

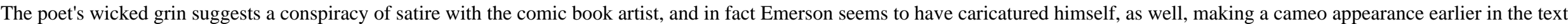

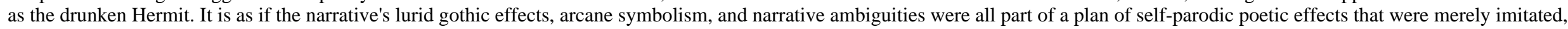
illustrated, and exaggerated by Emerson.

21

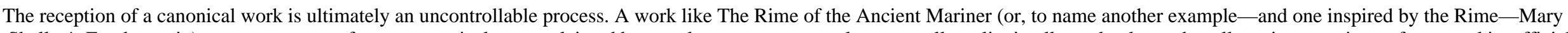

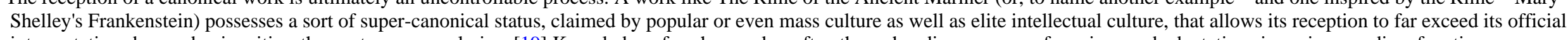

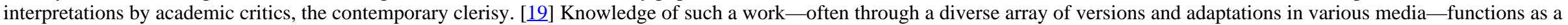

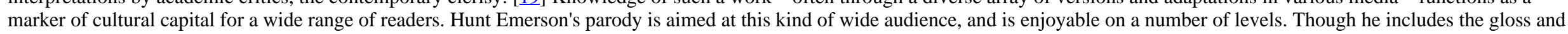

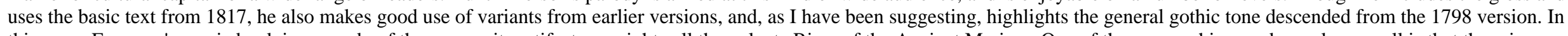

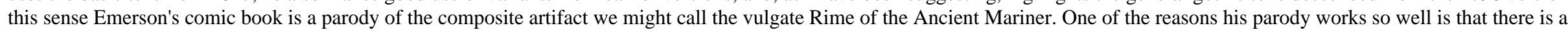

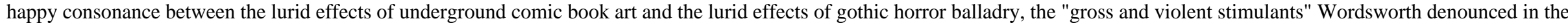

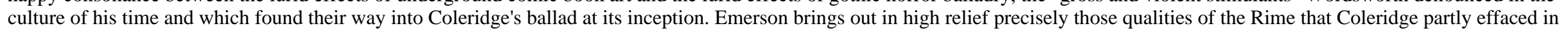

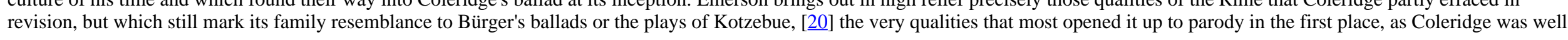
aware.

\section{The Roots of the Ancient Mariner: Mystery and Parody}

22

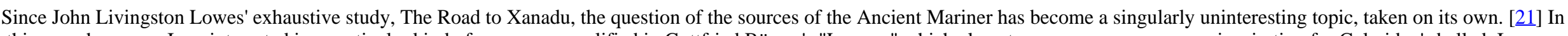

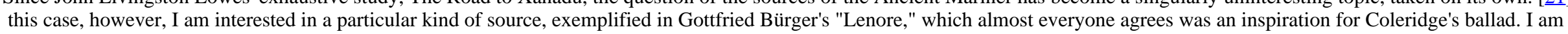

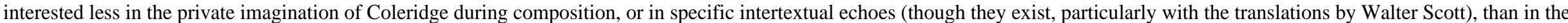

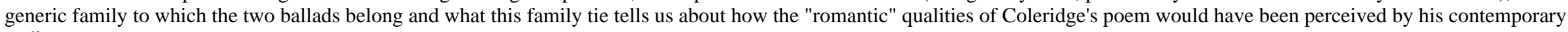
audience.

23

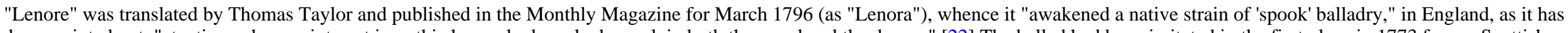

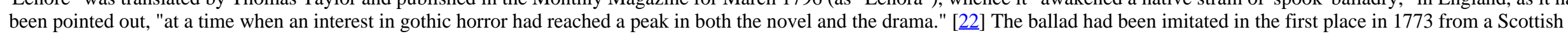

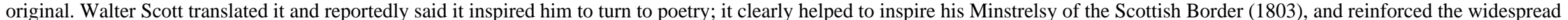

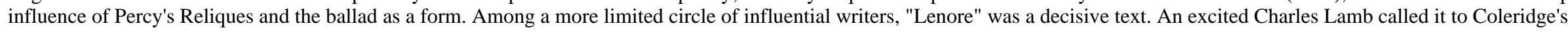




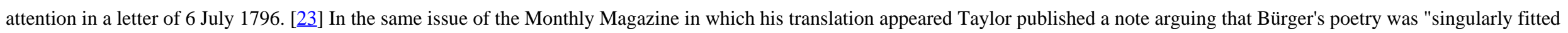
to become national popular song" because of his "impetuous diction," and praised his style in terms now recognizably Romantic:

Bürger is every where distinguished for manly sentiment and force of style. His extraordinary powers of language are founded on a rejection of the conventional phraseology of regular poetry, in favour of popular forms of expression, caught by the listening artist from the voice of agitated nature.

$$
\text { pp. 117-18 }
$$

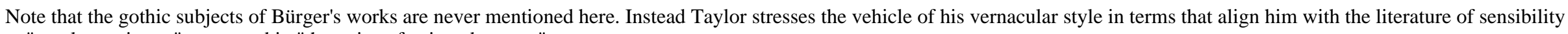
- "manly sentiment" expressed in "the voice of agitated nature."

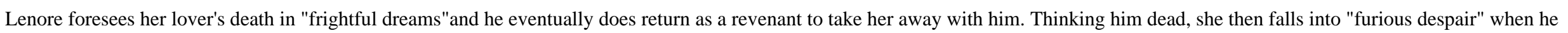
fails to return home from the crusades:

"Go out, go out, my lamp of life;

In endless darkness die:

Without him I must loathe the earth,

Without him scorne the skye."

And so despaire did rave and rage

Athwarte her boiling veins;

Against the Providence of God

She hurlde her impious strains.

She bet her breaste, and wrung her hands,

And rollde her tearlesse eye,

From rise of morne, till the pale stars

Again did freeke the skye.

sts. 21-23

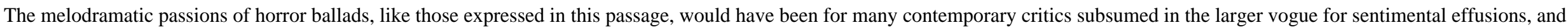
both would have been seen as the result of a new dominance in literature of the popular taste.

25

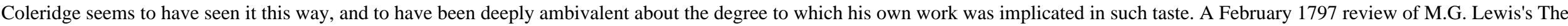
Monk attributed to Coleridge opens by declaring that "The horrible and preternatural have usually seized on the popular taste, at the rise and decline of literature."

Most powerful stimulants, they can never be required except by the torpor of an unawakened, or the languor of an exhausted, appetite. The same phaenomenon, therefore, which we hail as a favourable omen in the belles lettres of Germany, impresses a degree of gloom in the compositions of our countrymen. We trust, however, that satiety will banish what good sense should have prevented; and that, wearied with fiends, incomprehensible characters, with shrieks, murders, and subterraneous dungeons, the public will learn, by the multitude of the manufacturers, with how little expense of thought or imagination this species of composition is manufactured. But, cheaply as we estimate romances in general, we acknowledge, in the work before us, the offspring of no common genius. [24]

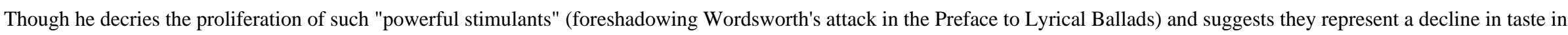




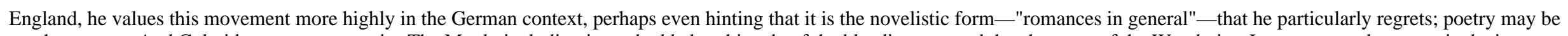

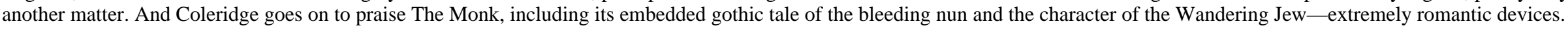

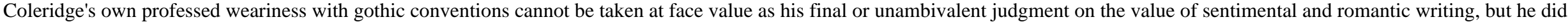
profess such weariness. One month after this review appeared, he wrote to William Lisle Bowles:

indeed I am almost weary of the Terrible, having been an hireling in the Critical Review for these last six or eight months-I have been lately reviewing the Monk, the Italian,

Hubert de Sevrac \& \& \& \& — - in all of which dungeons, and old castles, \& solitary Houses by the Sea Side, \& Caverns, \& Woods, \& extraordinary characters, \& all the tribe of

Horror \& Mystery, have crowded on me-even to surfeiting.-— [25]

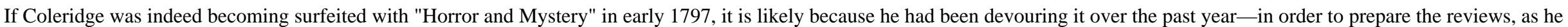

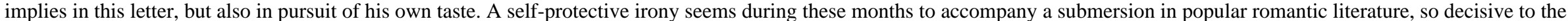

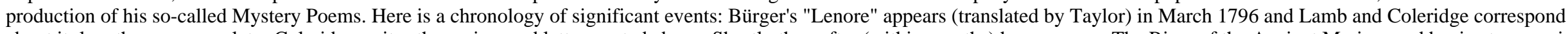

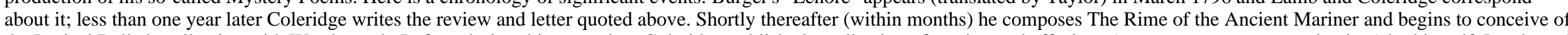

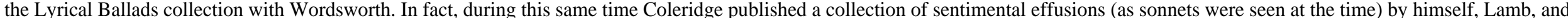

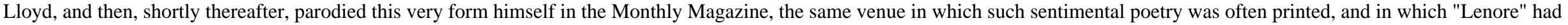

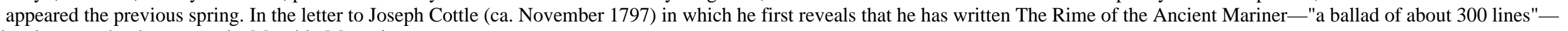
he also says that he sent to the Monthly Magazine

three mock Sonnets in ridicule of my own, \& Charles Lloyd's, \& Lamb's, \&c \&c -in ridicule of that affectation of unaffectedness, of jumping \& misplaced accent on common-place epithets, flat lines forced into poetry by Italics (signifying how well \& mouthis[h]ly the Author could read them, puny pathos \&c \&c-the instances are almost all taken from mine \& Lloyd's poems--I signed them Nehemiah Higginbottom. I think they may do good to our young Bards.-[26]

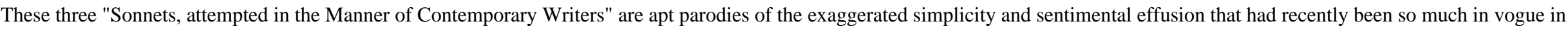
Coleridge's own circle. It has been pointed out that the first poem works best as a self-parody.

PENSIVE at eve on the hard world I mused,

And my poor heart was sad; so at the MOON

I gazed, and sighed, and sighed; for ah how soon

Eve saddens into night! mine eyes perused

With tearful vacancy the dampy grass

That wept and glitter'd in the paly ray:

And I did pause me on my lonely way

And mused me on the wretched ones that pass

Oe'r the bleak heath of sorrow. But alas!

Most of myself I thought! when it befel,

That the soothe spirit of the breezy wood

Breath'd in mine ear: "All this is very well,

But much of ONE thing, is for NO thing good."

Oh my poor heart's INEXPLICABLE SWELL! [27]

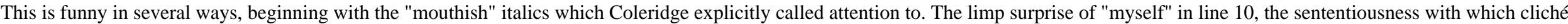

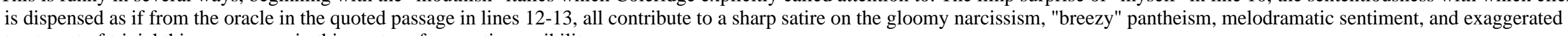
treatment of trivial things common in this poetry of romantic sensibility. 


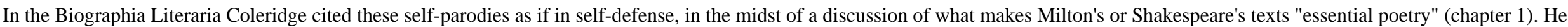
admits that he had earlier "adopted a laborious and florid diction," but implies that he has now moved beyond such youthful romantic excess:

Every reform, however necessary, will by weak minds be carried to an excess, that itself will need reforming. The reader will excuse me for noticing, that I myself was the first to expose risu honesto [with honest laughter] the three sins of poetry, one or the other of which is the most likely to beset a young writer. So long ago as the publication of the second number of the Monthly Magazine, under the name of NEHEMIAH HIGGINBOTTOM I contributed three sonnets, the first of which had for its object to excite a good-natured laugh at the spirit of doleful egotism, and at the recurrence of favorite phrases, with the double defect of being at once trite, and licentious. ...

\section{I, 26-27}

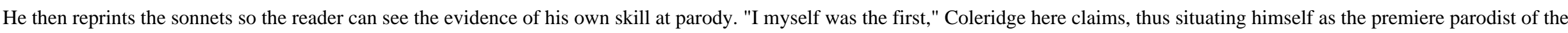

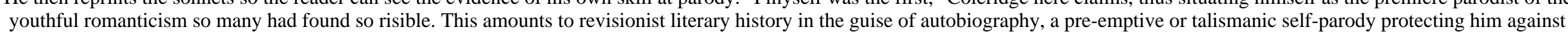

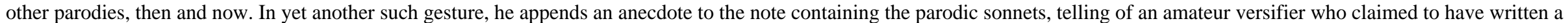

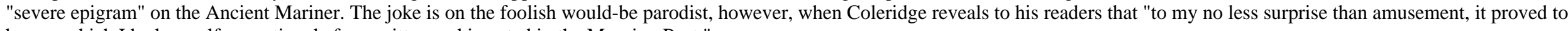
be one which I had myself some time before written and inserted in the Morning Post."

To the Author of the Ancient Mariner.

Your poem must eternal be,

'Dear sir! it cannot fail,

'For 'tis incomprehensible

'And without head or tail.

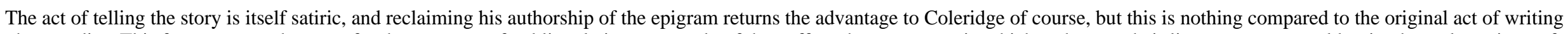

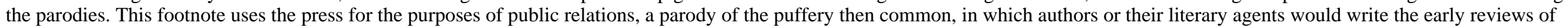

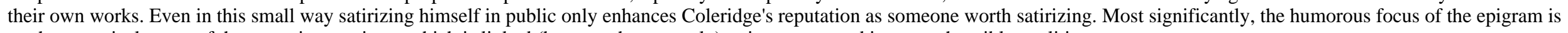
on the canonical status of the poem in question-which is linked (however humorously) to its opaque and incomprehensible qualities.

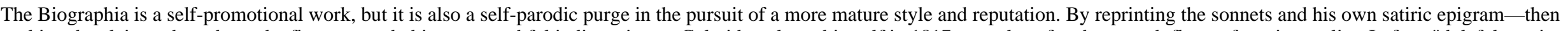

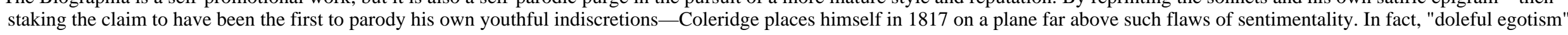

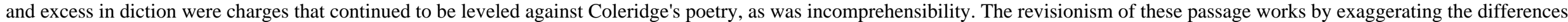
between then and now, the 1796-98 and 1817, in order to elevate the latter as a new era giving rise to a new species of poetry in Coleridge's oeuvre.

28

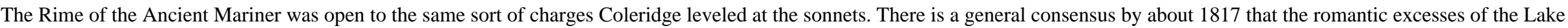

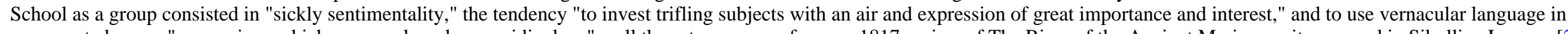

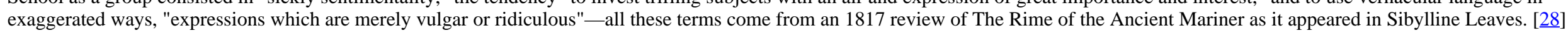

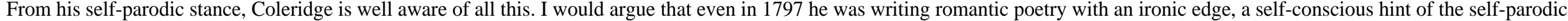

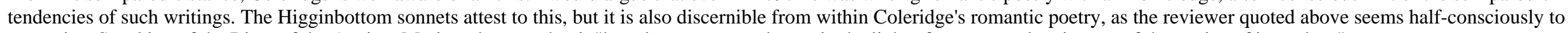
recognize. Speaking of the Rime of the Ancient Mariner, he says that it "has always appeared to us in the light of a very good caricature of the genius of its author."

It displays, in fact, all the strength and all the weakness, all the extravagances and eccentricities, all the bold features, and peculiar grimace, if we may so express ourselves, of his intellectual physiognomy, and in forming an opinion respecting the talents which he possesses, this composition may serve the very same purpose which an overcharged drawing of a countenance could answer ....

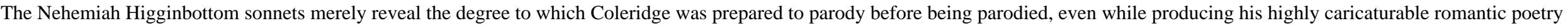

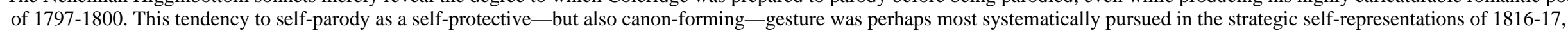




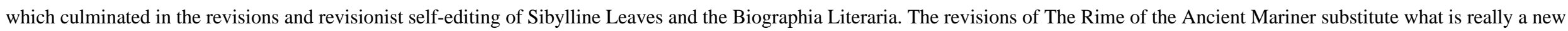

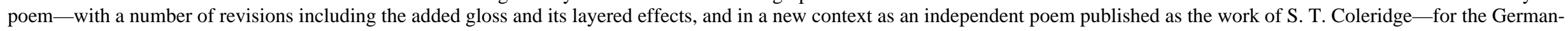

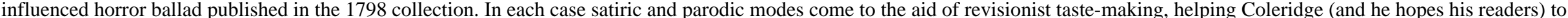

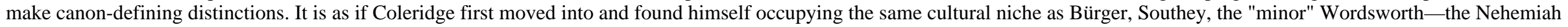

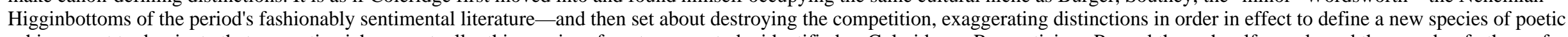

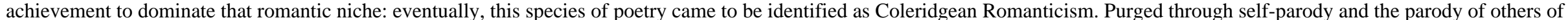

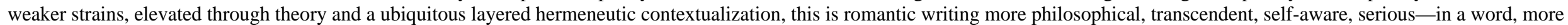

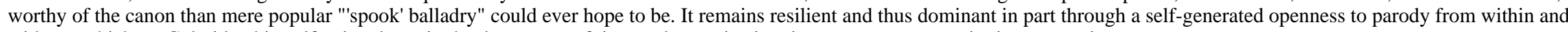
without, which, as Coleridge himself pointed out, in the due course of time and canonization, is one way to turn satire into encomium.

\section{Notes}

$[*]$

My general thanks to Jeffrey, for teaching me how to read comics.

[1]

Marilyn Gaull, "Romantic Humor: The Horse of Knowledge and the Learned Pig," Mosaic 9.4 (1976): 43.

[2]

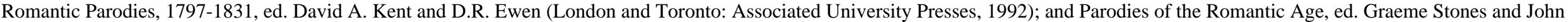
Strachan, 5 vols. (London: Pickering \& Chatto, 1999).

[3]

Linda Hutcheon, foreword to Romantic Parodies, ed. Kent and Ewen, pp. 7-8.

[4]

Linda Hutcheon, A Theory of Parody: The Teachings of Twentieth-Century Art Forms (New York: Methuen, 1985$)$ p. 37.

[5]

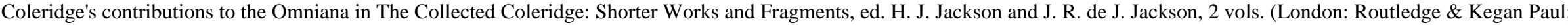
Princeton: Princeton University Press, 1995) vol. I, p. 305.

[6]

Coleridge, Biographia Literaria, ed. James Engell and W. Jackson Bate, 2 vols. (Princeton and London: Princeton University Press and Kegan Paul, 1983) vol. II, p. 6 (chapter 14).

[7]

Monthly Review (January 1819), 24-28; rept. Coleridge: the Critical Heritage, ed. J. R. de J. Jackson (New York: Barnes \& Noble, 1970) pp. 399-412.

[8]

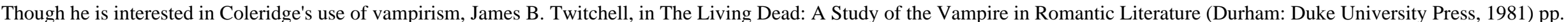

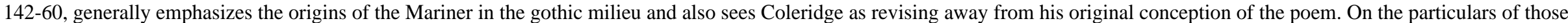
revisions, see Jack Stillinger, Coleridge and Textual Instability: The Multiple Versions of the Major Poems (New York and Oxford: Oxford University Press, 1994) pp. 70-73.

[9] 


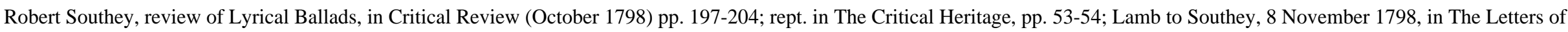

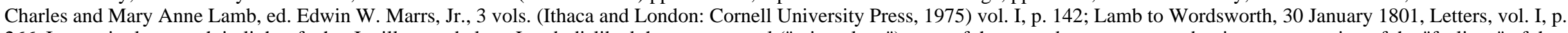

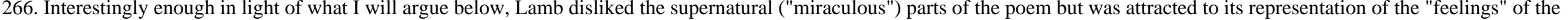
narrator.

\section{[11]}

J.G. Lockhart, "Essays on the Lake School," Blackwood's Edinburgh Magazine (October 1819): 3-12; rept. in The Critical Heritage, pp. 436-51.

$[12]$

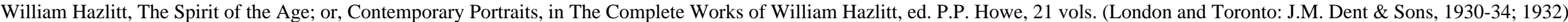
vol. 11, pp. 34-35.

[13]

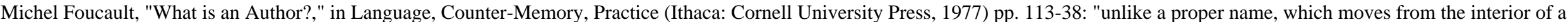

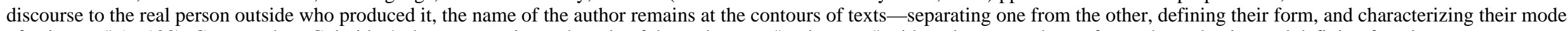
of existence" (p. 123). Cases such as Coleridge's, however, point to the role of the author as a "real person" with real agency who performs these shaping and defining functions.

[14]

Coleridge, Table Talk, in The Collected Coleridge, ed. Carl Woodring, 2 vols (Routledge; Princeton: University Press, 1990) vol. I, p. 149.

[15]

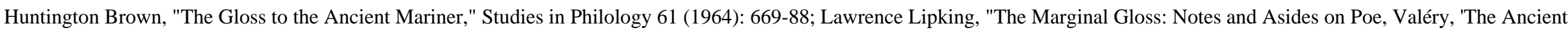

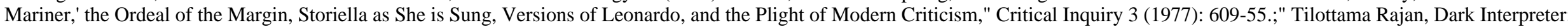

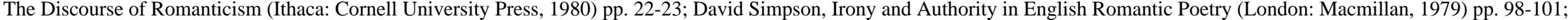
Jerome J. McGann, The Beauty of Inflections: Literary Investigations in Historical Method and Theory (Oxford: Clarendon press, 1985) pp. 135-72.

\section{[16]}

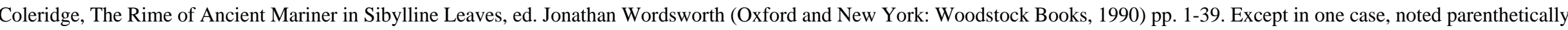
below (as "1798"), I cite the text in this edition. That passage is taken from Lyrical Ballads, 1798, ed. Jonathan Wordsworth (Oxford and New York: Woodstock Books, 1990).

D. M. Moir, "The Rime of the Auncient Waggonere," in Romantic Parodies, ed. Kent and Ewen, pp. 163-68.

Hunt Emerson, The Rime of the Ancient Mariner, Crack Comics edition, colored by Carol Bennett (London: Knockabout Comics, 1989; see Emerson's Website:

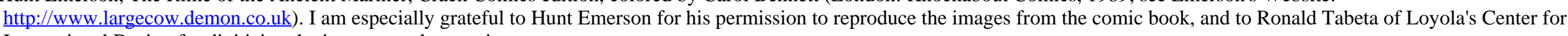
Instructional Design for digitizing the images on short notice.

[19]

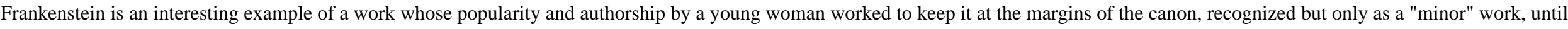

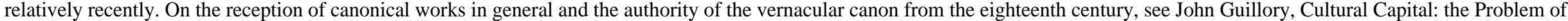
Literary Canon Formation (Chicago and London: University of Chicago Press, 1993). 


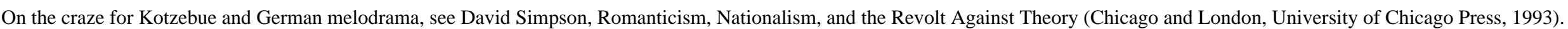

$[21]$

Jonathan Livingston Lowes, The Road to Xanadu: A Study in the Ways of the Imagination (London: Constable, 1927).

$[22]$

Marilyn Gaull, English Romanticism: The Human Context (New York: Norton, 1988) p. 269.

[23]

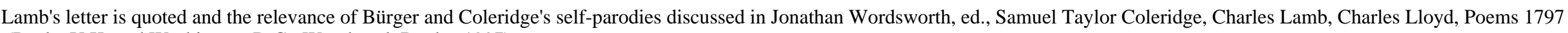
(Poole, U.K. and Washington D.C.: Woodstock Books, 1997).

[24]

Coleridge, review of M.G. Lewis's The Monk, in The Collected Coleridge: Shorter Works and Fragments, vol. I, pp. 57-65.

[25]

Letter to Bowles, 16 March 1797, in Collected Letters of Samuel Taylor Coleridge, ed. Earl Leslie Griggs, 6 vols. (Oxford: Clarendon Press, 1956-71) vol. I, pp. 317-19.

[26]

Letter to Cottle, ca. 20 November 1797, Collected Letters, vol. I, pp. 356-58.

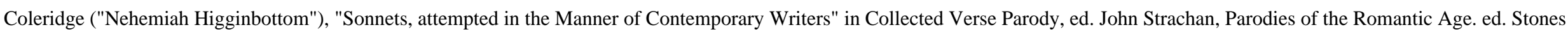

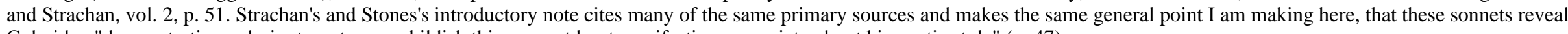
Coleridge "demonstrating a desire to put away childish things, or at least manifesting an anxiety about his poetic style" (p. 47).

[28]

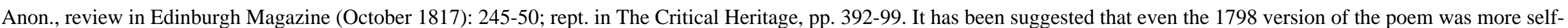

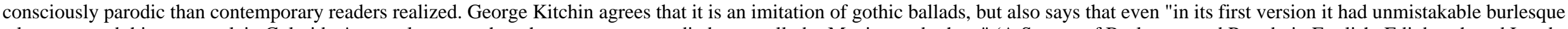

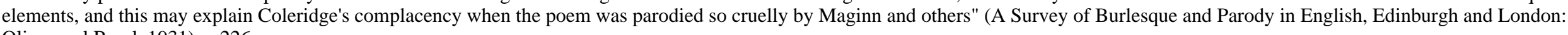
Oliver and Boyd, 1931) p. 226.

Auteur : Steven E. Jones

Titre : 'Supernatural, or at Least Romantic': the Ancient Mariner and Parody

Revue : Romanticism on the Net, Numéro 15, août 1999

URI : http://id.erudit.org/iderudit/005872ar

DOI : 10.7202/005872ar

Copyright (C Michael Eberle-Sinatra 1996-2002 — All rights reserved

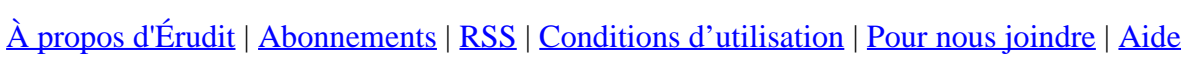

Consortium Érudit (C) 2015 